\title{
The Effect of Air Pollution on some Biochemical Parameters of Leaves of Three Tree Species Growing in the Industrial Area in Jeddah, Saudi Arabia
}

\author{
Shaheen, A. M., Al-Toukhy, A. A. and Hajar, A. S. \\ Biological Sciences Department, Faculty of Science, King Abdulaziz University, \\ Saudi Arabia.
}

\begin{abstract}
The effect of industrial emissions on the levels of certain biochemical measurements in leaves of Camphor (Cinnamomum camphora), Henna (Lawsonia inermis), and Bougainvillea (Bougainvillea spectabilis) trees growing in the industrial zone in Jeddah - Saudi Arabia and Hada Al-Shame area (control) was done. Overall results showed that the content of chlorophyll a and b, total chlorophyll, carotenoids and protein in the plant leaf of the trees growing in the industrial zone were less comparing with the leaves of the trees growing in the control area.
\end{abstract}

\section{Introduction}

Chlorophyll measurement is an important tool to evaluate the effects of air pollutants on plants (Joshi et al., 2009), since it plays an important role in plant metabolism and the reduction in of it corresponds directly to plant growth. Abbasi, et al., (2004) and Tripathi, et al. (2009) reported that chlorophyll content of plants varies from species to species; age of the leaf and also with the pollution level as well as with other biotic and a biotic conditions. Agbaire and Esiefarienrhe, (2009) indicated that whereas certain pollutants increase the total chlorophyll content, others decrease it. Chauhan and Joshi (2010) reported that wheat and mustard plants grown at polluted sites showed significant reduction in total chlorophyll and carotenoid.

Joshi and Swami (2007) and Seyyednejad and Koochak (2011) reported significant reduction in carotenoid content of different plants grown at polluted sites. Several researchers have reported reduced carotenoid content under air pollution (Joshi et al., 2009; Tiwari et al., 2006). Saquib et al. (2010) reported that the root biomass and chlorophyll a showed maximum reduction than any other selected parameters studied in the stressed area. Prasad and Rao (1981) found decrease in protein and carbohydrate content in petroleum-coke treated plants. Williams and Banerjee (1995) found considerable reduction in chlorophyll and protein content in leaves of Mangifera indica and Shorea robusta affected by the pollution in the industrial area. Verma and Singh (2006) noticed marked alterations in photosynthetic pigments and protein content in foliar tissues as affected by pollution. Also, Trivedi and Singh (1995) noticed significant reduction in protein content in a few plants as a result of fly ash particulates.

The aim of this investigation was to determine the effect of industrial emissions on the levels of some biochemical parameters in leaves of three plant species growing under industrial area (polluted) with those growing in unpolluted areas. The chosen parameters were 
chlorophyll $a$, chlorophyll $b$, total chlorophyll, carotenoids and protein.

\section{Materials and Methods}

\section{Study area}

This study was conducted at Jeddah city industrial area, which is situated between $21^{\circ} 24^{\prime} 37^{\prime \prime} \mathrm{N}$ latitude and $39^{\circ} 14^{\prime} 30^{\prime \prime} \mathrm{E}$ longitude and the control area (the Agricultural Research Station, Hada Al-Sham, King Abdulaziz University at a distance of $120 \mathrm{~km}$ north-east of Jeddah) which situated between $21^{\circ} 47^{\prime} 50^{\prime \prime} \mathrm{N}$ latitude and $39^{\circ} 43^{\prime} 33^{\prime \prime} \mathrm{E}$ longitude in the West of Saudi Arabia.

\section{Plant Materials}

Three plant species with the same age, namely Bougainvillea (Bougainvillea spectabilis), Camphor (Cinnamomum camphora) and Henna (Lawsonia inermis) were selected for this study, as they were common in Jeddah industrial area (polluted) and the control area (unpolluted).

\section{Chlorophyll $(a+b)$ and carotenoids content measurements:}

Samples (four discs each) were taken from fully expanded leaves of each plant and were extracted with acetone $80 \%$ in a water bath at $80^{\circ} \mathrm{C}$. Full extraction of chlorophyll and carotenoids was achieved when the sample was discolored. Four replicates were prepared per plant species. Absorbance was read in a spectronic 20+spectrophotometer at wavelength 645 and $663 \mathrm{~nm}$ and read against an $80 \%$ acetone solvent blank. That was done according to the method described by Arnon (1949) and Lichtenthaler (1987).

\section{Determination leaf nitrogen and protein}

Leaf nitrogen and protein contents were determined as described by Andreas and
Gunter (1994). Nitrogen content was estimated from the nitrogen content of the leaves (\%) by a Kjeldahl automatic Automatic kjeldhel According to A.O.A.C. (2006). The Protein concentration was done by multiplying the percentage of nitrogen $\times$ coefficient of a protein (6.25) for protein concentration, according to A.O.A.C. (2006).

\section{Experimental Design}

A completely randomized design with 4 replications were used to study each plant species separately where the industrial zone of Jeddah (polluted area) and the Hada Al-Shame (control area) were the treatments.

\section{Statistical Analysis}

Statistical analysis of the obtained data were statistically analyzed through analysis of variance and mean separation procedures after the assumption of the analysis of variance were tested and applied according to ElNakhlawy (2010) using SAS (2006).

\section{Results and Discussion}

\section{Nitrogen and protein contents in the plant species}

\section{Bougainvillea trees}

\section{Analysis of variance}

Analysis of variance of the protein and nitrogen contents in the plant leaves under the effects of the industrial pollutants and the control area (Table 1) showed significant effects at $\mathrm{p} \leq 0.05$ for the protein and nitrogen contents in the plant leaves of Bougainvillea trees, no significant in the plant leaves of Camphor and significant effects at $\mathrm{p} \leq 0.01$ in the plant leaves of Henna. 
Table (1). Analysis of variance of protein, nitrogen contents in plant leaves and nitrogen content in soil in the industrial zone and control area.

\begin{tabular}{|l|l|l|l|}
\hline \multirow{2}{*}{ S.O.V. } & \multirow{2}{*}{ df } & MS & Bougainvillea \\
\cline { 3 - 4 } & & Protein in plant leaves & Nitrogen in plant leaves \\
\cline { 3 - 4 } & 1 & $8.7780^{*}$ & $0.2244^{*}$ \\
\hline Locations & 6 & 0.971 & 0.0249 \\
\hline Error & & Camphor & Nitrogen in plant leaves \\
\cline { 3 - 4 } & & Protein in plant leaves & $0.0200^{\text {NS }}$ \\
\hline & 1 & $0.775^{\text {NS }}$ & 0.0075 \\
\hline Locations & 6 & 0.294 & \\
\hline Error & & Henna & Nitrogen in plant leaves \\
\cline { 3 - 4 } & & Protein in plant leaves & $2.83^{* *}$ \\
\hline & 1 & $110.558^{* *}$ & 0.034 \\
\hline Locations & 6 & 1.32 & \\
\hline Error & & &
\end{tabular}

Ns: not significant at $\mathrm{p} \leq 0.05$.

${ }^{*}, * *$ : significant at $\mathrm{p} \leq 0.05$ and $\mathrm{p} \leq 0.01$, respectively.

\section{Comparison between the means}

\section{Bougainvillea trees}

As shown in Table (2) the Bougainvillea plant leaves in the industrial zone had protein and nitrogen contents less than in the plant leaves of Hada Al-Sham (control) with no significant values. Protein contents were 17.297 and $19.392 \%$ in the industrial zone and the control, respectively.

\section{Camphor trees}

As shown in Table (2) the Camphor plant leaves in the industrial zone had protein and nitrogen contents less than in the plant leaves of Hada Al-Sham (control) with no significant values. Protein contents were 7.425 and $8.047 \%$ in the industrial zone and the control, respectively.

\section{Henna trees}

As shown in Table (2) the plant leaves in the industrial zone had protein and nitrogen contents less than in the plant leaves of Hada Al-Sham (control) with significant values. Protein and $\mathrm{N}$ contents in the control area are around twice them under the industrial area.

Table (2). Means of protein, nitrogen in plant and nitrogen in soil under the three species in the industrial zone and control area.

\begin{tabular}{|l|c|c|}
\hline \multirow{2}{*}{ Locations } & \multicolumn{2}{|c|}{ Means (\%) } \\
\cline { 2 - 3 } & Bougainvillea \\
\cline { 2 - 3 } & $17.297 \mathrm{~b}^{*}$ & Nitrogen in plant \\
\hline Industrial Zone & $19.392 \mathrm{a}$ & $2.767 \mathrm{~b}$ \\
\hline Hada Al-Sham & \multicolumn{2}{|c|}{ Camphor } \\
\hline \multirow{2}{*}{} & Protein in plant & Nitrogen in plant \\
\cline { 2 - 3 } & $7.425 \mathrm{a}$ & $1.188 \mathrm{a}$ \\
\hline Industrial Zone & $8.047 \mathrm{a}$ & $1.288 \mathrm{a}$ \\
\hline Hada Al-Sham & & Henna \\
\hline & Protein in plant & Nitrogen in plant \\
\cline { 2 - 3 } & $8.565 \mathrm{~b}$ & $1.370 \mathrm{~b}$ \\
\hline Industrial Zone & $16.00 \mathrm{a}$ & $2.560 \mathrm{a}$ \\
\hline Hada Al-Sham & & \\
\hline
\end{tabular}

\footnotetext{
*Means followed by the same letter are not significantly different according to LSD at $(\mathrm{p} \leq 0.05)$.
} 
Plant protein is an essential component for the plant growth. Significantly lower concentration of total proteins in leaves of all tree species was recorded in the industrial area as compared to the control area. This results are confirmed with the results of (Trivedi and Singh, 1995; Williams and Banerjee,1995 and Verma and Singh, 2006).

A decrease in protein content under heavy metal stress has been reported in other plant species such as Lupinus albus (Costa and Spitz, 1997) and L. minor. (Mohan and Hosetti, 1997).

\section{Total chlorophyll, chlorophyll a and chlorophyll b and carotenoid contents}

\section{Bougaivillea trees}

\section{Analysis of variance}

Analysis of variance of chlorophyll a and chlorophyll $\mathrm{b}$, total chlorophyll and carotenoid contents in the plant leaves under the effects of the industrial pollutants and the control area (Table 3) showed significant effects at $p \leq 0.05$ for these four characters except the chlorophyll $\mathrm{b}$ of Bougaivillea trees, which not significantly affected by the pollution sources.

Table (3). Analysis of variance of chlorophyll a, chlorophyll b, total chlorophyll and carotenoid contents in leaves of Bougainvillea under the effects of the industrial zone and control area.

\begin{tabular}{|c|c|c|c|c|c|}
\hline \multirow{2}{*}{ S.O.V. } & \multirow{d}{*}{\begin{tabular}{c}
$\mathrm{d}$ \\
\cline { 3 - 6 }
\end{tabular}} & $\begin{array}{c}\mathrm{r} \\
\text { chlorop } \\
\text { hyll a }\end{array}$ & $\begin{array}{c}\text { chlorop } \\
\text { hyll b }\end{array}$ & $\begin{array}{c}\text { total } \\
\text { chlorop } \\
\text { hyll }\end{array}$ & $\begin{array}{c}\text { caroten } \\
\text { oid }\end{array}$ \\
\hline $\begin{array}{c}\text { Locati } \\
\text { ons }\end{array}$ & 1 & $0.272^{*}$ & $0.026^{\mathrm{NS}}$ & $0.4675^{*}$ & $0.0522^{*}$ \\
\hline Error & 6 & 0.034 & 0.0155 & 0.0642 & 0.0062 \\
\hline
\end{tabular}

: not significant at $\mathrm{p} \leq 0.05$

*: significant at $\mathrm{p} \leq 0.05$.

\section{Comparison between the means}

As shown in Table (4) the plant leaves in the industrial zone had chlorophyll a and total chlorophyll contents less than in the plant leaves of Hada Al-Sham (control) with significant values, while chlorophyll $b$ was insignificant affected.
The carotenoid content in the plant leaves was around five times in the control than under the industrial pollutants, with values of 0.2483 and $0.0868 \mathrm{mg} / 100 \mathrm{~g}$, respectively.

Table (4). Means of chlorophyll a, chlorophyll b, total chlorophyll and carotenoid in plant leaves of Bougainvillea (Bougainvillea spectabilis) in the industrial zone and control area.

\begin{tabular}{|c|c|c|c|c|}
\hline \multirow{2}{*}{$\begin{array}{c}\text { Locatio } \\
\mathbf{n}\end{array}$} & $\begin{array}{c}\text { chloroph } \\
\text { yll a }\end{array}$ & $\begin{array}{c}\text { chloroph } \\
\text { yll b }\end{array}$ & $\begin{array}{c}\text { total } \\
\text { chloroph } \\
\text { yll }\end{array}$ & $\begin{array}{c}\text { caroteno } \\
\text { id }\end{array}$ \\
\hline $\begin{array}{c}\text { Industri } \\
\text { al Zone }\end{array}$ & $0.586 \mathrm{~b}^{*}$ & $0.298 \mathrm{a}$ & $0.885 \mathrm{~b}$ & $0.0868 \mathrm{~b}$ \\
\hline $\begin{array}{c}\text { Hada } \\
\text { Al- } \\
\text { Sham }\end{array}$ & $0.955 \mathrm{a}$ & $0.413 \mathrm{a}$ & $1.368 \mathrm{a}$ & $0.2483 \mathrm{a}$ \\
\hline
\end{tabular}

Means followed by the same letter are not significantly different according to LSD at $(\mathrm{p} \leq 0.05)$.

\section{Camphor trees}

\section{Analysis of variance}

Analysis of variance of chlorophyll a, chlorophyll $\mathrm{b}$, total chlorophyll and carotenoid contents in the plant leaves under the effects of the industrial pollutants and the control area (Table 5) showed no significant effects at $\mathrm{p} \leq 0.05$ for the three chlorophyll characters, while carotenoid content significantly affected by the industrial pollution at $\mathrm{p} \leq 0.01$.

Table (5). Analysis of variance of chlorophyll a, chlorophyll $b$, total chlorophyll and carotenoid in plant leaves of Camphor in the industrial zone and control area.

\begin{tabular}{|l|l|c|c|c|c|}
\hline & & \multicolumn{4}{|c|}{ MS } \\
\cline { 3 - 6 } S.O.V. & $\begin{array}{l}\text { f } \\
\text { f }\end{array}$ & $\begin{array}{c}\text { chlorop } \\
\text { hyll a }\end{array}$ & $\begin{array}{c}\text { chlorop } \\
\text { hyll b }\end{array}$ & $\begin{array}{c}\text { total } \\
\text { chlorop } \\
\text { hyll }\end{array}$ & $\begin{array}{c}\text { caroten } \\
\text { oid }\end{array}$ \\
\hline $\begin{array}{l}\text { Locati } \\
\text { ons }\end{array}$ & 1 & $0.1559^{\mathrm{NS}}$ & $0.0105^{\mathrm{NS}}$ & $0.2475^{\mathrm{NS}}$ & $0.0929^{* *}$ \\
\hline Error & 6 & 0.0611 & 0.0122 & 0.1131 & 0.0063 \\
\hline
\end{tabular}

${ }^{\mathrm{Ns}}$ : not significant at $\mathrm{p} \leq 0.05$.

${ }^{* *}$ : significant at $\mathrm{p} \leq 0.01$.

\section{Comparison between the means}

As shown in Table (6) the plant leaves in the industrial zone had chlorophyll a, chlorophyll $\mathrm{b}$ and total chlorophyll contents without significant differences than the control 
area, but carotenoid content was around four times in the control than under the industrial pollutants.

Table (6). Means of chlorophyll a, chlorophyll b, total chlorophyll and carotenoid contents in plant leaves of Camphor in the industrial zone and control area.

\begin{tabular}{|c|c|c|c|c|}
\hline \multirow{2}{*}{ Location } & \multicolumn{4}{|c|}{ Means (mg/100 g) } \\
\cline { 2 - 5 } & chlorophyll a & chlorophyll b & $\begin{array}{c}\text { total } \\
\text { chlorophyll }\end{array}$ & carotenoid \\
\hline $\begin{array}{c}\text { Industrial } \\
\text { Zone }\end{array}$ & $0.304 \mathrm{a}^{*}$ & $0.1010 \mathrm{a}$ & $0.405 \mathrm{a}$ & $0.0695 \mathrm{~b}$ \\
\hline $\begin{array}{c}\text { Hada Al- } \\
\text { Sham }\end{array}$ & $0.583 \mathrm{a}$ & $0.1735 \mathrm{a}$ & $0.757 \mathrm{a}$ & $0.2850 \mathrm{a}$ \\
\hline
\end{tabular}

Means followed by the same letter are not significantly different according to LSD at $(\mathrm{p} \leq 0.05)$.

\section{Henna trees}

\section{Analysis of variance}

Analysis of variance of chlorophyll a and chlorophyll b, total chlorophyll and carotenoid contents in the plant leaves under the effects of the industrial pollutants and the control area (Table 7) showed significant effects at $p \leq 0.01$ for chlorophyll $\mathrm{a}$, chlorophyll $\mathrm{b}$ and total chlorophyll in the plant leaves of Henna trees, while carotenoid content in the plant leaves was not significantly affected by the industrial pollution at $\mathrm{p} \leq 0.05$.

Table (7). Analysis of variance of chlorophyll a, chlorophyll b, total chlorophyll and carotenoid contents in plant leaves of Henna in the industrial zone and control area.

\begin{tabular}{|c|c|c|c|c|c|}
\hline \multirow[b]{2}{*}{ S.O.V. } & \multirow[b]{2}{*}{ df } & \multicolumn{4}{|c|}{ MS } \\
\hline & & chlorophyll a & chlorophyll b & $\begin{array}{c}\text { total } \\
\text { chlorophyll }\end{array}$ & carotenoid \\
\hline Locations & $\frac{1}{1}$ & $3.329^{* *}$ & $0.055^{* *}$ & $0.653^{* *}$ & $0.286^{\mathrm{NS}}$ \\
\hline Error & 6 & 0.010 & 0.005 & 0.026 & 0.058 \\
\hline
\end{tabular}

\section{Comparison between the means}

As shown in Table (8) the plant leaves in the industrial zone had chlorophyll a, chlorophyll $\mathrm{b}$ and total chlorophyll contents less than in the plant leaves of Hada Al-Sham (control) with significant values. The carotenoid content in the plant leaves was not significant affected by the industrial pollutants, compared the control area.

Table (8). Means of chlorophyll a, chlorophyll b, total chlorophyll and carotenoid contents in plant leaves of Henna in the industrial zone and control area.

\begin{tabular}{|c|c|c|c|c|}
\hline \multirow{2}{*}{ Location } & \multicolumn{4}{|c|}{ Means (mg/100 g) } \\
\cline { 2 - 5 } & $\begin{array}{c}\text { chlorophyll } \\
\mathbf{a}\end{array}$ & $\begin{array}{c}\text { chlorophyll } \\
\mathbf{b}\end{array}$ & $\begin{array}{c}\text { total } \\
\text { chlorophyll }\end{array}$ & carotenoid \\
\hline $\begin{array}{c}\text { Industrial } \\
\text { Zone }\end{array}$ & $0.389 \mathrm{~b}^{*}$ & $0.136 \mathrm{~b}$ & $0.525 \mathrm{~b}$ & $0.092 \mathrm{a}$ \\
\hline $\begin{array}{c}\text { Hada Al- } \\
\text { Sham }\end{array}$ & $0.092 \mathrm{a}$ & $0.301 \mathrm{a}$ & $1.0970 \mathrm{a}$ & $0.470 \mathrm{a}$ \\
\hline
\end{tabular}
according to LSD at $(\mathrm{p} \leq 0.05)$.

The results of this study of the three trees species showed that the composition of chlorophyll and carotenoid pigments in the plant leaf of the trees growing under the industrial pollutants were less comparing with the leaves of the trees growing in the control. These results are confirmed with the results of Mage et al. (1996) and Saquib et al. (2010).

The lower amount of chlorophyll a, chlorophyll b, total chlorophyll and carotenoids under polluted environment were also noted in several other studies (Singh et al. 1985; Singh et al. 1990; Malabari et al. 1991; Dhir et al. 1999; Nighat et al. 1999, 2000; Saquib, 2008; Iqbal et al. 2010; Chauhan and Joshi, 2010). Several researchers have reported reduced carotenoid content under air pollution (Joshi et al., 2009; Tiwari et al., 2006).

\section{Conclusion}

1. Protein contents of the plant leaves were $17.297 \%, 7.425 \%$ and $8.565 \%$ in Bougainvillea, Camphor and Henna, respectively under the industrial zone compared with $19.392 \%, 8.047 \%$ and $16.00 \%$, respectively under the control area.

2. Chlorophyll b, total chlorophyll and carotenoid contents were higher under Hada Al-Sham than industrial conditions in Bougainvillea trees. 
3. Only carotenoid content in the Camphor leaf was significantly higher under the control than the industrial conditions with around 4 times.

4. Chlorophyll $\mathrm{a}, \mathrm{b}$ and total chlorophyll were significantly higher in the Henna leaf under the control than the industrial zones, while carotenoid content did not significantly affected by the locations

5. The reduction biochemical parameters in leaves of the three plant species studied at the industrial area clearly indicates the deleterious effect of air pollution on plant health.

6. Based on the above study, it is evident that Camphor (Cinnamomum camphora), Henna (Lawsonia inermis), and Bougainvillea (Bougainvillea spectabilis) trees can be used as a bioindicator to monitor the air pollutants.

\section{References}

Abbasi, S., Chari, A. Gajalakshmi, K.B., Ramesh, N. and Ramasamy, E.B. (2004) Approaches to greenbelt design, J. Inst. Pub. Hlth. Engi., 3: 42-49.

Agbaire, P.O. and Esiefarienrhe, E. (2009) Air pollution tolerance indices (apti) of some plants around Otorogun gas plant in Delta State, Nigeria. J. Appl. Sci. Environ. Manage, 13 (1): 11-14. www.bioli ne.org.br/ja.

Andreas, B. and Gunter, K. (1994) "Air pollutant stress changes the steady state transcript levels of three photosynthesis genes", Environmental Pollution, 88: 57-65.

AOAC (2006) Official Methods of Analysis of AOAC; $18^{\text {th }}$ edition, January 24.

Arnon, D.I. (1949) Copper enzymes in isolated chloroplasts, polyphenoxidase in beta vulgaris, Plant physiology 24: $1-15$.

Chauhan, A. and Joshi, P.C. (2010) Effect of Ambient Air Pollutants on Wheat and Mustard Crops Growing In The Vicinity Of Urban and Industrial Areas, New York Science Journal; 3 (2): 52-60. (ISSN: 15540200).

Costa, G. and Spitz, E. (1997) Influence of cadmium on soluble carbohydrates, free amino acids, protein content of in vitro cultured Lupinus albus, Plant science 128: 131-140. DOI: 10.1016/S01689452(97)00148-9.

Dhir, B., Sharma, M.P., Mahmooduzzafar, S. and Iqbal, M. (1999) Form and function of Achyranthes aspera Linn. under air pollution stress, J. Environ. Biol. 20:19-23. OSTI ID: 348686; Journal ID: JEBIDP; ISSN 0254-8704; TRN: 990700494.
El-Nakhlawy, F. S. (2010) Experimental Design and Analysis in Scientific Research. Sci. Pub. Center, King Abdulaziz University, Jeddah, Saudi Arabia.

Giri, S., Shrivastava, D., Deshmukh, K. and Dubey, P. (2013) Effect of Air Pollution on Chlorophyll Content of Leaves, Curr. Agri. Res: 1 (2), doi: http://dx.doi.org/10.12944/CARJ.1.2.04.

Iqbal, M., Mahmooduzzafar, S., Nighat, F. and Khan, P.R. (2010) Photosynthetic, metabolic and growth responses of Triumfetta rhomboidea to coal-smoke pollution at different stages of plant ontogeny, $J$. Plant Interactions 5: 11-19. DOI: 10.1080/1742914 0902996165.

Joshi, N., Chauhan, A. and Joshi, P.C. (2009) Impact of industrial air pollutants on some biochemical parameters and yield in wheat and mustard plants, Environmentalist, 29: 398-404. DOI.10.1007/s106 69-009-9218-4.

Joshi, P.C. and Swami, A. (2007) Physiological responses of some tree species under roadside automobile pollution stress around city of Haridwar, India, Environmentalist; 27: 365-374. DOI.10.1007/s106 69-007-9049-0.

Lichtenthaler, H.K. (1987) Chlorophylls and carotenoids: pigments of photosynthetic membranes, Methods Enzymol, 148: 350-382. DOI: 10.1016/0076-6879 (87)48036-1.

Lowry, O.H., Rosebroiugh, N.J., Farr, A.L. and Randall, R.J. (1951) Protein measurement with the Folin phenol reagent, J. Biol. Chem. 193:265-275.

Mage, D., Ozolins, G., Peterson, P., Webster, A., Orthofer, R., Vandeweerd, V. and Gwynne, M. (1996) Urban air pollution in mega-cities of the world. Atmospheric Environment; 30: 681-686.

Malabari, A.A., Ahmad, Z. and Saquib, M. (1991) Effect of air pollution on Gnephalium pensylvanicum willd-a cropland weed. Geobios 18:7-10.

Mohan, B.S. and Hosetti, B.B. (1997) Potential phytotoxicity of lead and cadmium to Lemna minor L. growth in sewage stabilization ponds, Environ. Pollut., 98: 233-236. DOI: 10.1016/S0269-7491(97)00125-5

Nighat, F., Mahmooduzzafar, S. and Iqbal, M. (1999) Foliar responses of Peristrophe bicalyculata to coal smoke pollution. J. Plant Biol. 42:205-212. DOI:10.1007/BF03030480.

Nighat, F., Mahmooduzzafar, S. and Iqbal, M. (2000) Stomatal conductance, photosynthetic rate and pigment content in Ruellia tuberose leaves as affected by coal-smoke pollution. Biol. Plant 43:263-267. DOI:10.1023/A:1002712528893.

Prajapati, S.K. and Tripathi, B.D. (2008) Seasonal variation of leaf dust accumulation and pigment content in plant species exposed to urban particulates pollution. Journal of Environmental Quality 37: 865-870. doi:10.2134/jeq2006.0511.

Prasad, B.J. and Rao, D.N. (1981) Growth responses of Phaseolus aureus plants to petro-coke pollution, Journal of Experimental Botany 32:1343-1350.

Saquib, M. (2008) Effect of coal smoke pollution on the biomass and chlorophyll pigments of Brassica juncea. Ecoprint 15: 1-6. doi: 10.3126/eco.v15i 0.1935 . 
Saquib, M. Ahmad, A. and Ansari, K. (2010) Morphological and Physioligical Responses of Croton Bonplandianum Baill. to air Pollution. ECOPRINT 17: 35-41. www.nepjol.info/index.php/eco; www.ec osnepal.com.

SAS. (2006) SAS Institute Inc. Cary Nc., USA (Soft Ware Statistical Program)

Seyyednejad, S. M. and Koochak, H. (2011) A Study on Air Pollution-Induced Biochemical Alterations in Eucalyptus Camaldulensis. Australian Journal of Basic and Applied Sciences, 5 (3): 601-606. ISSN 1991-8178.

Singh, S.N., Yunus, M. and Singh, N. (1990) Effect of sodium metabisulphite on chlorophyll, protein and nitrate reductase activity of tomato. Sci. Total Environ. 81:269-274.

Singh, S.N., Yunus, M., Srivastava, K., Kulshreshtha, K. and Ahmad, K.J. (1985) Response of Calendula officinalis $\mathrm{L}$ to long-term fumigation with $\mathrm{SO}_{2}$. Env. Pollution 39:17-25.
Tiwari, S., Agrawal, M. and Marshall, F.M. (2006) Evaluation of ambient air pollution impact on carrot plants at a sub urban site using open top chambers. Environmental Monitoring and Assessment, 119: 1530. DOI:10.1007/s10661-005-9001-z.

Tripathi, A.K., P.B. Tiwari, Mahima, A. and Singh, D. (2009) Assessment of air pollution tolerance index of some trees in Moradabad city, India. J. Enviro. Biol., 30: 545-550.

Trivedi, M.L. and Singh, R.S. (1995) Reduction in protein contents in a few plants as indicators of air pollution. Pollut. Res., 14: 269-273.

Verma, A. and Singh, S.N. (2006) Biochemical and ultrastructural changes in plant foliage exposed to auto-pollution. Environmental Monitoring and Assessment 120: 585-602. DOI:10.1007/s10661005-9105-5.

Williams, A.J. and Banerjee, S.K. (1995) Effect of thermal power plant emission on the metabolic activities of Mangifera indica and Shorea robusta. Environment and Ecology, 13: 914-919. 
تأثنير تلوث الهواء على بعض الصفات الكيموحيوي لأوراق ثلاثة أنواع من الأشجار تتموا في المنطقة الصناعية بجدة، المملكة العربية السعودية

شاهين، أحمد محمد عبدالرحيم؛ والطوخي، عبدالمنعم عبدالمجي؛؛ وآل حجر، عبدالرحمن سعيد قسم علوم الأحياء، كلية العلوم، جامعة الملك عبدالعزيز، جذة، المدلكة العربية السعودية

الدستخلص. تم دراسة تأثير الانبعاثات الصناعية على مسنويات بعض القياسات البيوكيميائية في أوراق

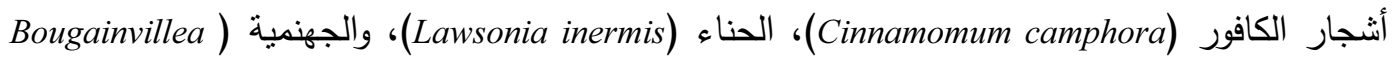
(spectabilis

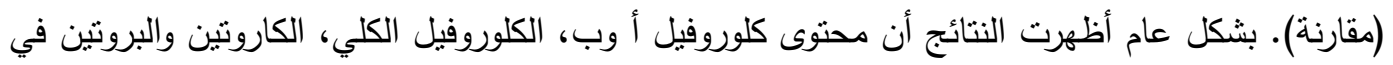
أوراق نبانات الأنواع الثالاثة من الأثجار التي تتمو في المنطقة الصناعية كان أقل مقارنة مع أوراق الثان الأثنجار الني تتمو في منطقة المقارنة.

الكلمات الدفتاحية: الكلوروفيل، الكاروتينات، البروتين، صبغات النثيل الضوئي، تلوث الهواء، المناطق

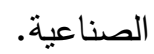

